\title{
The Identification, Taxonomy and Classification of Luminous Bacteria
}

\author{
By MARGARET S. HENDRIE, W. HODGKISS \\ AND J. M. SHEWAN \\ Torry Research Station, P.O. Box 3I, I35 Abbey Road, Aberdeen, AB98DG \\ (Accepted for publication 7 October 1970) \\ SUMMAR Y \\ The results of a study of $5 \mathrm{I}$ strains of luminous bacteria and 12 strains of \\ non-luminous bacteria from related genera show that the luminous bacteria \\ can be divided into three major groups. These groups span three genera, \\ namely Vibrio, Photobacterium and a suggested new genus, Lucibacterium, to \\ accommodate the 'Photobacterium harveyi' organisms. Revised descriptions \\ of the species are given.
}

\section{INTRODUCTION}

Luminous bacteria are not rare in the marine environment and they have occasionally been reported from non-marine sources. In the sea they are found in the water, as saprophytes and parasites on marine animals and living symbiotically in specialized organs in certain fish and cephalopods. Early workers assigned these bacteria to a variety of genera, but Beijerinck (I889) proposed that all luminous bacteria should be placed in one genus, Photobacterium, which is based on a single criterion, namely the ability to emit visible light. Later (I9I6) Beijerinck stated that some species were closely allied to the cholera vibrios, but since then there has been much confusion in the nomenclature and taxonomy of the luminous bacteria. Many species have been named on ecological grounds, e.g. Micrococcus physiculus, Micrococcus (Coccobacillus) acropomae, Achromobacter merluccius, Photobacterium sepiae, etc., and some new species have been described which show only minor differences from existing species.

Much of the literature on luminous bacteria deals with the metabolic systems and biochemical requirements of individual strains, but little has been published on the taxonomy of the group as a whole (see McElroy, I96I, for a review). In I954, Breed \& Lessel pointed out that these bacteria had been assigned to no fewer than 15 genera and numerous specified epithets had been used. Index Bergeyana (r966) lists 39 specific epithets that have been used with Photobacterium alone. Breed \& Lessel (I954) proposed that all luminous bacteria should be assigned to two genera, Photobacterium, which is placed in the family Pseudomonadaceae, and Vibrio. Spencer (I955) studied seven named strains and two new isolates and concluded that all luminous bacteria had close affinities with the genera Vibrio and Aeromonas.

In the seventh edition of Bergey's Manual (1957) all luminous bacteria are listed under Photobacterium and Vibrio as proposed by Breed \& Lessel (1954). In Photobacterium there are four species, Photobacterium phosphoreum, the type species, $P$. fischeri, $P$. harveyi and $P$. pierantonii. These species are fairly well described, but of the four species listed under Vibrio - Vibrio albensis, $V$. pierantonii, $V$. indicus and 
$V$. luminosus - only $V$. albensis, a non-marine type, has been adequately described. Prévot (I96I), in his Traité de Systématique Bactérienne, listed the same eight species under the same genera but selected $P$. fischeri as the type species of Photobacterium. Krassil'nikov (I959) listed eight species in Photobacterium with a further eight subspecies included under five of these species, and one species was included in Pseudomonas - Pseudomonas harveyi, a species originally placed in Achromobacter by Johnson \& Shunk (1936) and in Photobacterium in Bergey's Manual (7th edn) and in Prévot's Traité de Systématique Bactérienne.

NCMB

collection accession number

Table I. List of organisms used in the study

r

\section{Species (as received)}

$$
\begin{aligned}
& \text { Strain and/or other } \\
& \text { collection numbers }
\end{aligned}
$$

\section{Luminous strains}

$\left.\begin{array}{lc}\begin{array}{l}\text { Photobacterium splendidum } \\ P . \text { harveyi }\end{array} & 4 \\ P . \text { phosphoreum } & - \\ P . \text { sepiae } & - \\ P . \text { pierantonii } & \text { ATCC } 14546 \\ P . \text { albensis } & \text { ATCC } 14547 \\ P . \text { fischeri } & \end{array}\right\}$

Micrococcus physiculus Coccobacillus macrouri Photobacterium phosphoreum Pseudomonas lucifer

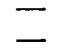

Coccobacillus sp. Micrococcus acropomae Coccobacillus macrouri C. macrouri -

Vibrio sp.

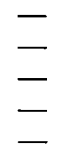

Photobacterium phosphoreum

$\begin{array}{ll}840 & - \\ 841 & - \\ 842 & - \\ 843 & - \\ 844 & -\end{array}$

\section{Source}

\author{
A. J. Kluyver, Delft, via \\ R. Spencer \\ J. Cruickshank, University \\ of Aberdeen, via \\ R. Spencer \\ T. Iijima, Osaka, Japan, \\ via R. Spencer
}

Y. Yasaki, Tokyo, Japan, via R. Spencer

T. Iijima, via R. Spencer J. Liston, T.R.S. (Liston, 1955)

N. K. Velankar, Mandapam, South India, via R. Spencer (deposited, 1958)

R. Spencer, Humber Laboratory, Hull

$$
\left.\begin{array}{l}
I_{2} B \\
I_{3}(=39 I) \\
I_{7}(=394) \\
7 g \\
\text { DLG I }
\end{array}\right\}
$$

N. K. Velankar, via R. Spencer (deposited 196I)

D. L. Georgala, Fishing Industry Research Institute, Rondebosch, South Africa, via R. Spencer U. Melchiorri-Santolini, Fiascherino (La Spezia), Italy 
NCMB

collection

accession number

I06I

Table I (cont.)

Species (as received)

Vibrio sp.
Strain and/or other collection numbers

314

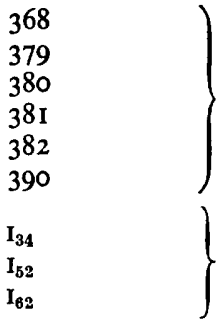

\begin{tabular}{|c|c|}
\hline I 447 & Vibrio sp. \\
\hline 1148 & Vibrio sp. \\
\hline 1149 & Vibrio sp. \\
\hline II 50 & Vibrio sp. \\
\hline II5I & Vibrio sp. \\
\hline II 52 & Vibrio sp. \\
\hline I 198 & - \\
\hline I 199 & - \\
\hline 1200 & - \\
\hline I 274 & Vibrio noctiluca \\
\hline 1275 & Photobacterium profundu \\
\hline 1276 & - \\
\hline I 277 & - \\
\hline 1278 & - \\
\hline 1279 & - \\
\hline I 280 & Photobacterium harveyi \\
\hline I 28I I & P. fischeri \\
\hline 1282 & P. phosphoreum \\
\hline
\end{tabular}

$U-1$

R-I

DLG 2

DLG 3

F 37

CB 95

ATCC 14126

ATCC 7744

ATCC I 1040
Source

J. I. W. Anderson,

Department of

Bacteriology, University

of Glasgow

R. Spencer, Humber Laboratory, Hull

\section{A. N. Bose, Central} Institute of Fisheries Technology, Ernakulam, South India

H. Weisglass, Zagreb, Yugoslavia (Weisglass \& Skreb, 1963; Weisglass \& Gavrilovic, 1963)

D. L. Georgala, via R. Spencer

R. Spencer, via J. C. Early ATCC. Originally deposited in ATCC by F. H. Johnson

I. P. Crawford (1954) (Pivnick \& Sabina, 1957)

W. Hodgkiss, T.R.S.

A. A. Miles, who obtained it from A. J. Kluyver (Miles \& Miles, I95I)

L. I. Fletcher, T.R.S. via W. Hodgkiss

J. Liston, T.R.S.

D. L. Georgala, T.R.S.

W. Hodgkiss, T.R.S.

W. Hodgkiss \& J. M. Shewan, T.R.S.

(Hodgkiss \& Shewan, I950; Shewan, Hobbs \& Hodgkiss, 1960)

\begin{tabular}{|c|c|c|}
\hline I 143 & $V$. marinus & $\begin{array}{l}\text { PS } 207 \\
\text { ATCC } 15382\end{array}$ \\
\hline I 144 & $V$. marinus & MP-1 \\
\hline NCIB & & \\
\hline 9243 & Aeromonas shigelloides & $\begin{array}{l}\text { C } 27 \\
\text { ATCC } 14030\end{array}$ \\
\hline
\end{tabular}

R. R. Colwell (Colwell \& Morita, 1964)

W. H. Ewing (Ferguson \& Henderson, 1947)

NCMB = National Collection of Marine Bacteria; NCIB = National Collection of Industrial Bacteria, both at Torry Research Station, Aberdeen. ATCC = American Type Culture Collection; T.R.S. = Torry Research Station. 
Clearly there is still much confusion in the classification of luminous bacteria and many of the descriptions given in current editions of manuals are inadequate for present-day requirements. With the desire to clarify the stiuation, we have made a new study of a collection of these organisms.

\section{METHODS}

Organisms. Table I lists the 5I strains of luminous bacteria and I 2 strains of nonluminous bacteria from 'related' genera that were used.

Media. All sea-water media contained natural sea water, aged as recommended by ZoBell (1946) (storage in the dark for a minimum of 3 weeks) and filtered before use and then diluted, 3 parts sea water to I part tap or distilled water. Sea-water-yeast peptone (SWYP): yeast extract powder (Oxoid), $0.3 \%$; peptone (Evans), $0.5 \%$ at pH $7 \cdot 4$. Agar (I.5\%, Difco) was added for the solid medium. Yeast peptone (pH 7.4): yeast extract powder, $0.3 \%$; peptone, $0.5 \%, \mathrm{NaCl}, 0.5 \%$ in distilled water (in some tests the $\mathrm{NaCl}$ concentration was altered as required). Glycerol calcium carbonate agar: yeast peptone agar with $3 \% \mathrm{NaCl}, \mathrm{I} \%$ glycerol and $0.5 \% \mathrm{CaCO}_{3}$. Plaice medium (the late Professor A. J. Kluyver, personal communication): minced fresh plaice $(200 \mathrm{~g}$.) was soaked in 4 1. tap water for $2 \mathrm{~h}$., boiled for $\mathrm{I} \mathrm{h}$. and filtered. Peptone $(0.5 \%)$ and $\mathrm{NaCl}(3 \%)$ were added, the broth adjusted to $\mathrm{pH} 7.3$, boiled and filtered. For a solid medium $2 \%$ agar was added. Sea-water lemco: Lab-lemco, I \%; peptone, $0.5 \%$ at $\mathrm{pH} 7.4$.

Stock cultures were maintained at $20^{\circ}$ on SWYP agar or sea-water lemco agar except Aeromonas shigelloides, which was maintained on yeast peptone agar. All tests on $A$. shigelloides were carried out in media containing $0.5 \% \mathrm{NaCl}$ as growth in sea water or $3 \% \mathrm{NaCl}$ media was unsatisfactory.

Temperature relationships. All cultures were streaked on SWYP agar plates, 10 strains per plate, and incubated at $\mathrm{I}$ and $5^{\circ}$ (for $2 \mathrm{I}$ days); 15,20 and $25^{\circ}$ ( 7 days) and 30 and $37^{\circ}$ (3 days). The plates were examined at intervals during incubation. As all strains except Vibrio marinus grew well at temperatures of 15 to $25^{\circ}$ and only some grew at either higher or lower temperatures, all subsequent tests were carried out at $20^{\circ}, V$. marinus being tested at $15^{\circ}$.

Morphology. Cultures grown in SWYP broth for 24 or $48 \mathrm{~h}$. were examined under a dry phase contrast microscope $(\times 240)$ for motility and shape of the living cells. Strains which were not observed to be motile in liquid medium were examined from $24 \mathrm{~h}$. SWYP agar slope culture as it had been noted that motile forms could occasionally be detected from a solid medium and not from a liquid medium. Smears for staining were prepared from a 2 day SWYP agar culture by suspending the bacteria in $2 \% \mathrm{NaCl}$ solution to prevent uptake of water by the cells, and fixed with methanol. The smears were then desalted by flooding with water for $5 \mathrm{~min}$. and allowed to dry before Gram-staining by Jensen's modification (Mackie \& McCartney, I960).

Bacteria required for electron microscopy came from 24 or $48 \mathrm{~h}$. cultures grown on SWYP agar, plaice agar or glycerol calcium carbonate agar. Suspensions were prepared by the following methods. (a) Bacteria were harvested from slopes into $5 \%$ ammonium acetate solution and washed three times by centrifugation at low speed (2000g) and then the deposit was suspended in ammonium acetate. A droplet of this suspension was placed on a grid. (b) Bacteria were harvested into $2.5 \% \mathrm{NaCl}$ con- 
taining $5 \%(\mathrm{v} / \mathrm{v})$ formalin and fixed for $30 \mathrm{~min}$. A drop of this suspension was placed on a grid, dried and was washed by floating the grid face down on distilled water for Io min. (c) Bacteria were fixed in formalin in sodium chloride solution as in $(b)$, washed twice in $5 \%$ ammonium acetate and a suspension in this solution placed on the grids.

Metal-shadowed preparations were made by drying the suspensions on Formvarcoated 200-mesh copper grids and shadowing with gold + palladium $(40+60)$ at an angle of $20^{\circ}$. For negatively stained preparations the suspensions were dried on carbonstabilized Formvar-coated grids and stained with either I \% phosphotungstic acid ( $\mathrm{pH} 7$; Brenner \& Horne, 1959) or I \% ammonium molybdate. After I min. the excess fluid was removed by touching the grid with filter paper. Specimens were examined in a Siemen's Elmiskop I with a double condenser system, a condenser aperture of $200 \mu \mathrm{m}$. and an objective aperture of $50 \mu \mathrm{m}$. Micrographs were recorded on Ilford N 50 plates.

Colony appearance was recorded after 3 days incubation on SWYP agar and appearance of growth in liquid medium after 2 days in SWYP broth.

Effect of $\mathrm{NaCl}$ on luminescence. Agar slopes of SWYP, plaice medium and glycerolcalcium carbonate media with 0.5 and $3 \% \mathrm{NaCl}$ and yeast peptone medium containing different amounts of $\mathrm{NaCl}(0.5, \mathrm{I}, \mathrm{I} \cdot 5,2,2.5$ and $3 \%$, were inoculated with a drop of a 2 day broth culture and examined in the dark room daily for 4 days and again after 7 days incubation. The observer spent $10 \mathrm{~min}$. in the dark room before examining the cultures to allow the eyes to become accommodated to the dark.

$\mathrm{NaCl}$ requirement and tolerance. Yeast peptone broth with no $\mathrm{NaCl}$ and with 5 , 7.5 and $10 \% \mathrm{NaCl}$ was inoculated from a 2 day SWYP broth culture. The extent of visible growth was recorded after 4,7 and I5 days incubation, and the tubes were examined for luminescence daily for 4 days.

Antibiotic sensitivity. This was tested by the method of Shewan, Hodgkiss \& Liston (1954). The vibriostatic compound ' $0 / \mathrm{r} 29$ ' (2,4-diamino-6,7-diisopropyl pteridine) was applied as filter-paper discs which had been saturated with a $0.1 \%$ solution in dioxan and dried (Schubert, 1962, modified). Yeast peptone agar was used as Spencer (1955) had suggested that sea water interfered with the action of terramycin. Since many strains did not grow enough on this medium to give a satisfactory result, the test was repeated on SWYP agar with compound o/I29 applied in duplicate, as a saturated aqueous solution in cups out from the agar, and as impregnated paper discs.

Biochemical tests. Acid production from carbohydrates and alcohols was tested using $\mathrm{I} \%$ of the substrate and $\mathrm{I} \%$ Andrade indicator in a sea-water peptone medium ( $1 \%$ peptone in $3:$ I sea water: distilled water). The 28 substrates tested were arabinose, rhamnose, ribose, xylose, fucose, glucose, fructose, galactose, mannose, lactose, sucrose, maltose, cellobiose, raffinose, trehalose, sorbose, cellulose, mannitol, dulcitol, sorbitol, glycerol, inositol, salicin, inulin, dextrin, laminarin, starch and glycogen. Results were recorded at I, 2, 4 and 7 days and then weekly up to 4 weeks.

Dissimilation of glucose was tested by the methods of Hugh \& Leifson (I953) and Leifson (1963), but in the latter medium, with filtered aged natural sea water instead of artificial sea water. Results were read after I, 2, 4 and 7 days, and at Io and I 4 days for strains showing little change after 7 days.

Oxidase was tested by the method of Kovacs (1956).

Tests for indole production, ammonia production from peptone, nitrate reduction, 
acetylmethylcarbinol production, methyl red reaction (Manual of Microbiological Methods, I957), 2,3-butanediol production (Bullock, 196I) and trimethylamine oxide (TMO) reduction (Wood \& Baird, I943) were made on 7 day cultures in sea-water media (indole, ammonia, nitrate) or in media supplemented with $3 \% \mathrm{NaCl}$.

Hydrolysis of Tweens was tested by Sierra's method (I957) using media with $3 \%$ $\mathrm{NaCl}$ and read at I, 2, 4 and 7 days.

Møller's method (1955) was used for the detection of lysine and ornithine decarboxylases and the production of alkaline products from arginine. The medium contained $3 \% \mathrm{NaCl}$ and results read at $\mathrm{I}, 2,4,7$ and 9 days.

Gelatin liquefaction was tested in stab cultures in SWYP + I2\% gelatin; growth and changes were recorded at I, 2, 4 and 7 days and weekly to 5 weeks. Strains showing slow liquefaction or no liquefaction were retained for 7 weeks.

Egg yolk reactions were tested on SWYP agar + egg yolk emulsion (Willis \& Hobbs, 1958); after 4 days plates were examined and tested for free fatty acids.

Esterase patterns were examined by starch gel electrophoresis by the method of Cann \& Willox (1965).

Base compositions of deoxyribonucleic acid were determined by Professor $\mathbf{M}$. Mandel by the buoyant density in caesium chloride method (Mandel, I966) for I 3 luminous strains representative of all the groups and subgroups differentiated by the morphological and biochemical tests. The base composition of the Pseudomonas species and three named luminous strains were determined by the thermal denaturation method (Marmur \& Doty, 1962) after preparation of the DNA by Marmur's method (I96I).

\section{RESULTS}

\section{Luminous strains}

All luminous strains were Gram-negative rods, and all except three were motile. Gram-stained preparations frequently showed pleomorphic forms. Morphology was most clearly seen in wet preparations under phase contrast and in electron microscope preparations. There were three morphological types.

I. Coccobacilli which, though motile, had a low proportion of motile forms in the culture and frequently appeared non-flagellate. The flagellate forms possessed only a single polar flagellum. Typical of this morphological group is Photobacterium phosphoreum (Pl. I, fig. I).

2. Motile slender slightly curved rods with a single polar flagellum (strains labelled Photobacterium splendidum and Vibrio albensis; Pl. 1, fig. 2) or a tuft of polar flagella (strains of P. fischeri; Pl. I, fig. 3).

3. Rods which are often long and unusual in that they have peritrichous flagella, but in addition to the many fine lateral flagella, have a much thicker flagellum at one or both poles. This type of flagellation was seen, for example, in strains of Photobacterium harveyi (Pl. I, fig. 4). Two types of flagella were also seen by Johnson, Zworykin \& Warren (I943) in electron microscopic studies of this species, but they did not report the position of attachment.

Preparations of Photobacterium harveyi NCMB I 280 showed fascicles of finer flagella (Pl. 2, fig. 5). The difference in the diameters of the thin and thick flagella can be seen in shadowed preparations (PI. 2, fig. 6). The diameters of the fine flagella were $\mathrm{I} 3$ to I $8 \mathrm{~nm}$. and those of the thick flagella 30 to $4 \mathrm{r} \cdot 6 \mathrm{~nm}$. In negatively stained preparations 
the thick flagellum was seen to possess a distinct sheath which was much less stable than the central core (I0 to I $2 \mathrm{~nm}$. diameter) of the flagellum (Pl. 2, fig. 7, 8). This sheathed structure of the flagellum has been reported for various Vibrio species, Vibrio metschnikovii (Follett \& Gordon, 1963), V. cholerae and V. parahaemolyticus (Ogasawara \& Kuno, I $964 a, b)$. Another morphological feature seen in strains of $P$. harvey $i$ was the presence of fimbriae.

Strains of Photobacterium fischeri and Vibrio noctiluca produced pale yellow pigmented colonies; all others were non-pigmented. No strains produced diffusible pigments.

Only one strain - Vibrio albensis - grew in salt-free broth and none grew in $10 \%$ $\mathrm{NaCl}$. Most strains grew in $5 \% \mathrm{NaCl}$ and growth in $7.5 \% \mathrm{NaCl}$ was confined to strains of Photobacterium harveyi and $P$. splendidum. Luminous strains were observed to emit light in media with $\mathrm{NaCl}$ concentrations from 0.5 to $3 \%$, and many were also luminous in yeast peptone broth containing $5 \% \mathrm{NaCl}$. All strains were capable of anaerobic growth.

All strains were insensitive to penicillin, but sensitive to streptomycin, chloramphenicol and polymyxin B; most were sensitive to terramycin. There did not appear to be any definite pattern in the strains insensitive to terramycin. Strains of Photobacterium harveyi and $P$. splendidum were insensitive to the vibriostatic compound o/129: all other strains showed some degree of sensitivity to this compound.

Glucose was metabolized fermentatively by all strains in the Leifson (1963) marine OF medium. In the Hugh \& Leifson (1953) medium 24 strains were fermentative: the remaining 27 strains did not grow satisfactorily in this medium.

Nitrate was reduced to nitrite by 49 of the 5 I strains. The methyl red reaction was positive in 50 strains, four giving a weak result. Ammonia was produced from peptone by all 5I strains. Trimethylamine oxide was reduced by 4I strains, three were negative, the remaining seven strains were not tested.

Of the 28 'sugars' tested, no acid or gas was produced from nine of these; namely, arabinose, rhamnose, xylose, sorbose, raffinose, cellulose, dulcitol, inositol, inulin. A further three sugars were occasionally attacked: ribose (by 12 strains), lactose (by two strains) and fucose (by one strain).

The results of the other tests are summarized in Table 2.

Esterases were seldom detected in strains falling into groups I and II (Table 2) except group I $d$; but they were detected in strains in groups III and IV. The pattern of esterases within a group was not homogeneous.

\section{Non-luminous strains}

The non-luminous strains were all motile Gram-negative rods possessing polar flagella. The Aeromonas and Vibrio species metabolized glucose fermentatively, were methyl red-positive (except Aeromonas shigelloides) and reduced nitrate to nitrite. The Pseudomonas species either attacked glucose by the oxidative pathway (NCMB I 29, $320,406)$ or did not attack glucose (NCMB 130, 224), were negative in the methyl red test and variable in reduction of nitrate. All strains produced ammonia from peptone. The results of the other tests are given in Table 2. 


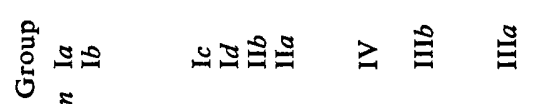
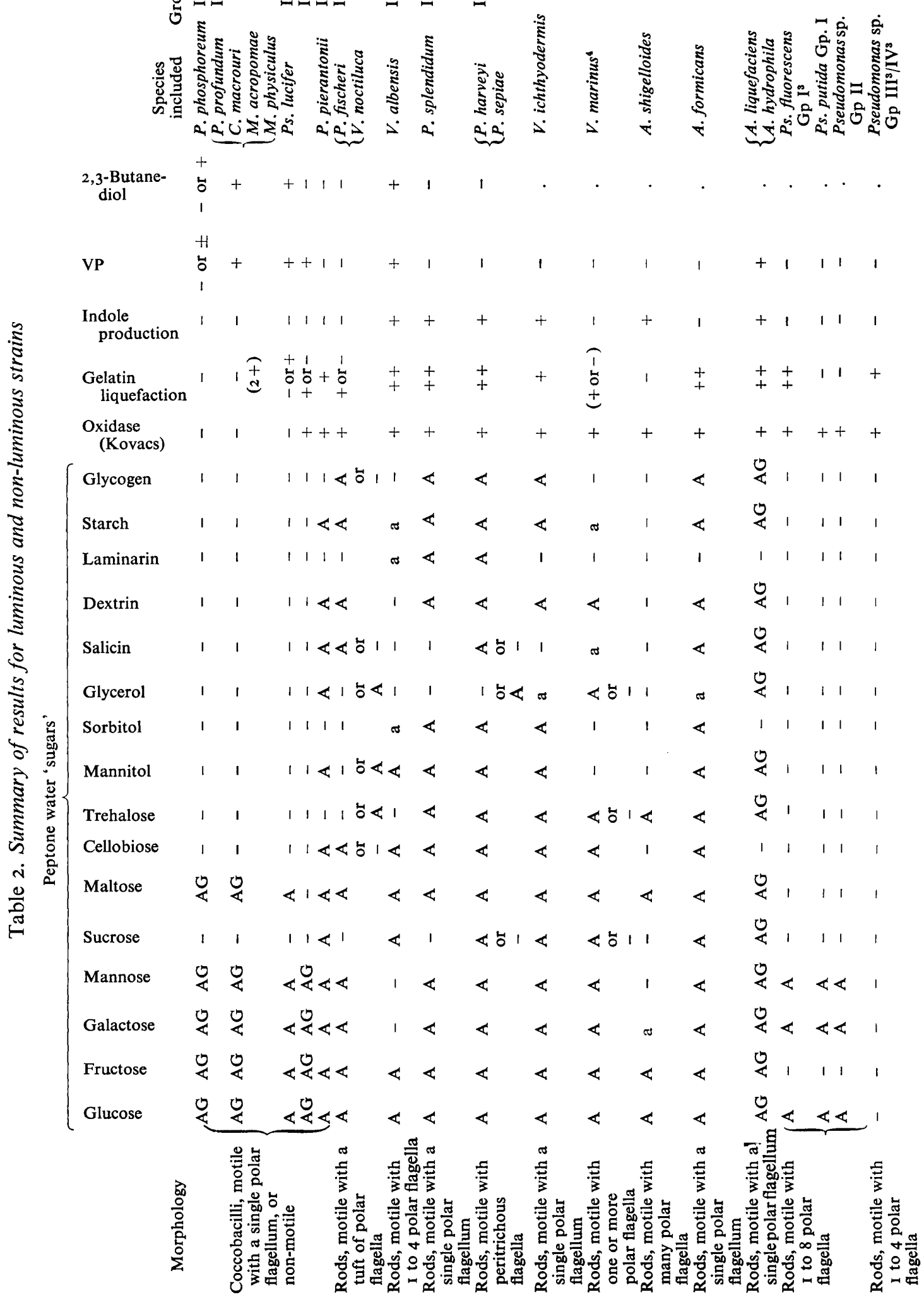


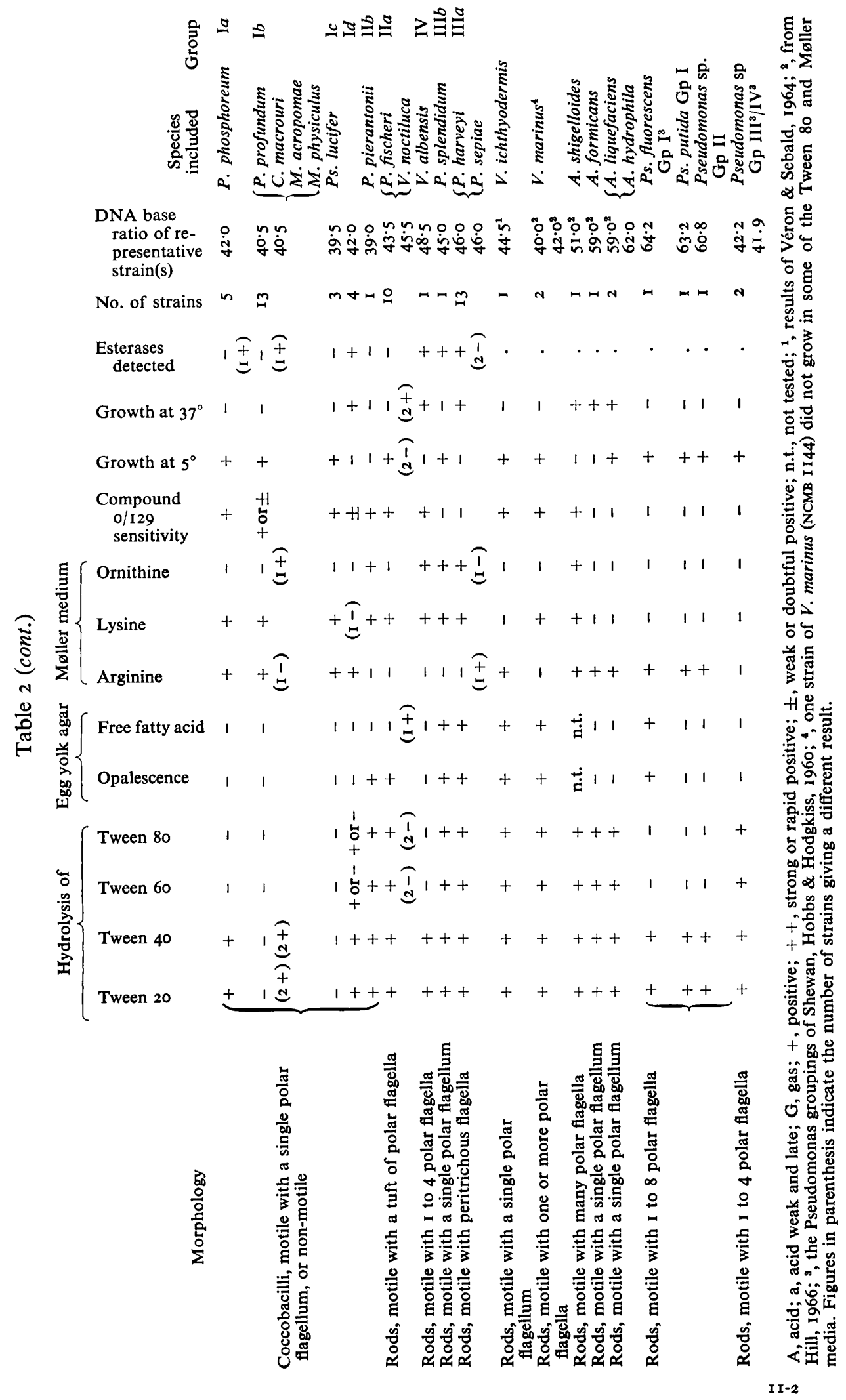




\section{DISCUSSION}

Table 2 shows that 44 of the luminous strains fall into three major groups (I $a, b, c, \mathrm{II} a$, III $a$ ) which correspond well with the three morphological divisions. Of the remaining seven strains, Vibrio albensis, the only non-marine strain, is unique, whereas the other six strains appear to be transitional between the main morphological and biochemical types, particularly the two strains labelled Photobacterium pierantonii and P. splendidum.

Groups $\mathrm{I} a, b$ and $c$ are all very similar and such differences as do exist appear to be of minor importance and to represent variation of strains within a single species, e.g. group $\mathrm{I} b$ produces acid and gas from carbohydrates whereas group $\mathrm{I} c$ is anaerogenic, otherwise they are identical. The only differences between group I $a$ and groups $\mathrm{I} b$ and $c$ are the variability in the VP and 2,3-butanediol tests in I $a$ and their ability to hydrolyse Tweens 20 and 40 , but two strains in $\mathrm{I} b$ also hydrolyse these Tweens. All group I strains examined have DNA base ratios of 39.5 to 42.0 moles \% guanine + cytosine $(\% \mathrm{G}+\mathrm{C})$. We recommend that all 2I strains in groups $\mathrm{I} a, b$ and $c$ should be combined in the species Photobacterium phosphoreum. Spencer (I955) proposed that $P$. phosphoreum should be assigned to the genus Vibrio as it was sensitive to the vibriostatic compound $0 / \mathrm{r} 29$ and dissimilated glucose fermentatively, but all the strains in this group ( $P$. phosphoreum) are Kovacs' oxidase-negative and are usually aerogenic in the breakdown of carbohydrates whereas Vibrio species are oxidase-positive and never aerogenic. The species $P$. phosphoreum should include species previously labelled $P$. profundum (Weisglass \& Gavrilovic, 1963), Pseudomonas lucifer, Coccobacillus macrouri, Micrococcus physiculus and Micrococcus (or Coccobacillus) acropomae.

The position of group $\mathrm{I} d$ is further away from groups $\mathrm{I} a, b$ and $c$ than these are from each other. Although the group I $d$ strains have much in common with the other group I strains, they attack hexoses only, are Kovacs' oxidase-positive, hydrolyse Tweens 20 and 40 (some strains also Tweens 60 and 80) and although VP-positive, they are 2,3butanediol negative. The groups $\mathrm{I} a, b$ and $c$ strains attack maltose in addition to hexoses, are oxidase-negative and never hydrolyse Tweens 60 and 80 . The DNA base ratio of the one strain from $\mathrm{I} d$ examined was identical with a strain of Photobacterium phosphoreum in group $\mathrm{I} a(42 \cdot 0$ moles $\% \mathrm{G}+\mathrm{C})$. This group appears to form a separate species, and we propose the name $P$. mandapamensis, since the first strain of this group was isolated at Mandapam.

The Io strains in group II $a$ fit closely to the second morphological type and are different from the organisms of group I in being oxidase-positive, not giving an alkaline reaction with arginine, and attacking a much wider range of carbohydrates anaerogenically. They are also the only pigmented group, the colonies being pale yellow. The DNA base ratios of the strains examined are 43.5 and 45.5 moles $\% \mathrm{G}+\mathrm{C}$. All strains in this group should be combined under the specific epithet fischeri which should be assigned to the genus Vibrio as suggested by Spencer (1955) as they are polar flagellate rods, fermentative in their action upon glucose, sensitive to compound o/ 29 and also have a DNA base ratio within the range for that genus ( 40 to 50 moles $\%$ $\mathrm{G}+\mathrm{C}$; Colwell \& Mandel, 1964). Furthermore, they are very similar to the working neotype strains of the non-luminous species Vibrio marinus (Colwell \& Morita, I964). Included in the species $V$. fischeri is the recently described species $V$. noctiluca (Weisglass \& Skreb, 1963).

The I 3 strains in group III $a$ also form a single species which differs from group I 
and group II $a$ in being insensitive to the vibriostatic compound o/129, indole-positive, much more actively proteolytic in gelatine, having an ornithine decarboxylase (except Photobacterium narveyi NCMB I 280, the type strain) and lipases which are active in egg yolk agar, in addition to having the peritrichous flagella of the third morphological type. The DNA base ratios of the strains examined were $45 \cdot 5$ to $46 \cdot 5$ moles $\% \mathrm{G}+\mathrm{C}$. The strains in this group should be combined under the specific epithet harveyi and should include the strain labelled $P$. sepiae, a name which is not considered to be legitimate (Index Bergeyana, 1966), and NCMB 42 which was originally labelled $P$. fischeri. Spencer (1955) believed that this group had affinities with the genus Aeromonas as it was insensitive to compound o/129. However, the harveyi group is peritrichate and has a DNA base ratio $(45.5$ to 46.5 moles $\% \mathrm{G}+\mathrm{C})$ which is well outside the range of the genus Aeromonas (59 to 62 moles \% G+C) (Hill, I966; Rosypal \& Rosypalova, I966). We recognize that this group (III $a$ ) has some affinities with the genus Vibrio, having a similar DNA base ratio and the sheathed structure of the thick polar flagellum seen in some strains is similar to that described for some Vibrio species (Follett \& Gordon, 1963; Ogasawara \& Kuno, 1964a, $b$ ). However, the possession of peritrichous flagella and insensitivity to compound o/129 leads us to suggest that the species should be assigned to a new genus for which we propose the name Lucibacterium (Latin: lux, lucis, light) for the genus with Lucibacterium harveyi (Johnson \& Shunk) comb.nov. as the type species.

The strain labelled Photobacterium splendidum (group III $b$ ) is identical with group III $a$ except that it has a single polar flagellum and a lower temperature range. This strain has been maintained in artificial culture for many years and it is possible that some of its properties may have been irretrievably lost, as has happened with some strains of the Vibrio fischeri group which are no longer luminous, although this property was observed by us when they were freshly isolated. The DNA base ratio of $P$. splendidum $(45.0$ moles $\% \mathrm{G}+\mathrm{C})$ is also near that of the group III $a$ strains and we believe that this organism may be a degenerate Lucibacterium harveyi.

The organism labelled Photobacterium pierantonii (group II $b$ ) is morphologically similar to those in group I, being a non-motile coccobacillus and having a low DNA base ratio (39.0 moles \% G $+\mathrm{C}$ ) similar to other strains in this group. Biochemically this organism is almost identical with those of group II $a$. In the seventh edition of Bergey's Manual (1957) there are two luminous species described which have the specific epithet pierantonii - Photobacterium pierantonii and Vibrio pierantonii. Our strain does not fit exactly the description of either species. Biochemically it is close to II $a$ $V$. fischeri, but morphologically is more like the Photobacterium species and its temperature range did not reach the value quoted for $V$. pierantonii. This might possibly be a single representative of a species but for the present we propose to group it as an atypical strain of $V$. fischeri.

The non-marine strain Vibrio albensis (group IV) is distinct from all the others. Morphologically it is similar to group II $a$, being a slender rod with one or more polar flagella. It is similar to group III in being actively proteolytic, indole-positive, but it is the only strain outside group I which is VP and 2,3-butanediol-positive. It has decarboxylases for lysine and ornithine like many other Vibrio species (Bain \& Shewan, 1968; Carpenter, Hart, Hatfield \& Wicks, 1968). The DNA base ratio was the highest of all the strains examined at 48.5 moles $\% \mathrm{G}+\mathrm{C}$ and is close to that of $V$. cholerae. Its similarity to $V$. cholerae has long been recognized (Bergey's Manual, 1957). 
It is therefore suggested that luminous bacteria should be classified into three genera, namely Photobacterium, Vibrio and a new genus, Lucibacterium, to accommodate organisms currently called $P$. harveyi and $P$. sepiae. The species to be included in the genus Vibrio are $V$. albensis and $V$. fischeri, and in the genus Photobacterium, $P$. phosphoreum, the present type species, with the addition $P$. mandapamensis as a further distinct species. The genus Lucibacterium would include $P$. splendidum as a degenerate form of $L$. harveyi.

We thank Professor M. Mandel for his help. The DNA base ratio estimations by the thermal denaturation method were done by Mr D. G. McLeod and the starch-gel electrophoresis examination for esterase patterns by Mrs Margaret E. Taylor of Torry Research Station.

\section{APPENDIX}

Our proposals for (i) modified and extended descriptions of the species named in this appendix and (ii) the generic descriptions of Photobacterium and Lucibacterium, are based on information from the present study, from the seventh edition of Bergey's Manual (I957) and from the work of Spencer (196r) on the chitinoclastic activities of luminous bacteria.

Species included in the genus Vibrio Pacini, 1854

\section{Vibrio albensis Lehmann \& Neumann, 1896}

(Synonyms: Elbe vibrio, Dunbar, I893; Microspira dunbari Migula, 1900.)

Rods, $\mathrm{I} \cdot 5$ to $3.0 \times 0.4$ to $0.7 \mu \mathrm{m}$., occurring singly and in pairs, sides parallel, ends rounded, axis frequently curved. Motile by means of polar flagella, usually one per cell, but occasional cells may have 2 or 4 flagella. Not encapsulated. Gram-negative.

Agar colonies: Off-white, translucent, circular, convex, entire margin, smooth, shiny, $\mathrm{I} \cdot \mathrm{O}$ to $2.0 \mathrm{~mm}$. diam. Good growth. Luminous. On sea-water agar the colonies are punctiform and luminous.

Broth: Good growth, thin pellicle, uniform turbidity, viscid deposit. Luminous 2 to 3 days.

Grows at $37^{\circ}$ but not at $5^{\circ}$. Grows in media containing o to $5 \% \mathrm{NaCl}$, no growth in $7.5 \% \mathrm{NaCl}$, luminescent in media with 0.5 to $3 \% \mathrm{NaCl}$. Growth in media at $\mathrm{pH} 6$ to $\mathrm{pH} 9$, no growth at $\mathrm{pH} 5$.

Aerobic, facultatively anaerobic.

Sensitive to chloramphenicol, streptomycin, aureomycin, terramycin, polymyxin B and 2,4-diamino-6,7-diisopropyl pteridine. Insensitive to penicillin.

Indole produced, acetylmethylcarbinol produced, 2,3-butanediol produced, nitrite produced from nitrate, ammonia produced from peptone, trimethylamine oxide reduced to trimethylamine. Methyl red test negative.

Oxidase- and catalase-positive.

Possesses decarboxylases for lysine and ornithine but does not produce alkaline products from arginine.

Hydrolyses Tweens 20, 40, 60 and 80 .

No opalescence or free fatty acids produced on egg yolk agar.

Gelatin liquefied.

Starch hydrolysed. 
Chitin digested.

Acid but no gas formed in glucose, sucrose, maltose, trehalose; weak acid production in fructose, mannose, mannitol, sorbitol, dextrin, starch and glycogen. No acid or gas in arabinose, rhamnose, xylose, ribose, fucose, galactose, lactose, sorbose, raffinose, cellobiose, cellulose, dulcitol, glycerol, inositol, adonitol, salicin, inulin, aesculin or laminarin.

Carbohydrate metabolism fermentative.

DNA base ratio 48.5 moles $\% \mathrm{G}+\mathrm{C}$.

Habitat: Fresh water, in human faeces and bile.

Vibrio fischeri (Beijerinck) Lehmann \& Neumann, I896.

(Synonyms: Die einheimischen Leuchtbacillen, Fischer, I888; Photobacterium fischeri Beijerinck, I889; Bacillus fischeri (Beijerinck) Trevisan, I889; Bacillus phosphorescens indigenus Eisenberg, I892; Bacterium phosphorescens indigenus Chester, 1897; Microspira fischeri (Beijerinck) Chester, r90r; Spirillum phosphorescens Holland, 1920; Vibrio phosphorescens Holland, 1920; Achromobacter fischeri (Beijerinck) Bergey et al. 1930; Vibrio noctiluca Weisglass \& Skreb, 1963.)

Short rods, $0.5 \times \mathrm{I} \cdot 0$ to $\mathrm{I} \cdot 5 \mu \mathrm{m}$, occurring singly and in pairs, sides parallel, ends rounded, axis straight or slightly curved. Stained preparations frequently show pleomorphism and polar staining. Motile by means of a tuft of polar flagella. Gramnegative.

Sea-water agar colonies: Off-white in young cultures, becoming pale yellow, translucent, circular, convex, entire margin, smooth, shiny $\mathrm{I} \cdot 0$ to $2 \cdot 0 \mathrm{~mm}$. diam. Usually luminous at I to 3 days. Growth moderately good.

Sea-water broth: Abundant growth, ring or thin pellicle, uniform turbidity, small deposit, usually luminous at 2 to 3 days.

Usually grows at $5^{\circ}$ but not at $37^{\circ}$. Growth and visible light usually emitted in media containing 0.5 to $5 \% \mathrm{NaCl}$, some strains grow in $7.5 \% \mathrm{NaCl}$; no growth without $\mathrm{NaCl}$. Growth from $\mathrm{pH} 6$ to $\mathrm{pH} 9$.

Aerobic, facultatively anaerobic.

Sensitive to chloramphenicol, streptomycin, polymyxin B and 2,4-diamino-6,7diisopropyl pteridine. Insensitive to penicillin. Sensitivity to terramycin and aureomycin varies from strain to strain.

Nitrite produced from nitrate; trimethylamine oxide reduced to trimethylamine; ammonia produced from peptone. Indole, acetylmethylcarbinol and 2,3-butanediol not produced.

Methyl red test positive.

Oxidase- and catalase-positive.

Usually has a lysine decarboxylase but not an ornithine decarboxylase nor produces alkaline products from arginine.

Tweens 20 and 40 hydrolysed, Tweens 60 and 80 usually hydrolysed.

Opalescence produced in egg yolk agar, production of free fatty acids variable.

Gelatin liquefied.

Starch hydrolysed.

Chitin may be digested.

Acid but no gas formed in glucose, fructose, galactose, mannose, maltose, dextrin and starch, and by some strains in cellobiose, trehalose, mannitol, glycerol, salicin and 
glycogen. No acid or gas formed in arabinose, rhamnose, ribose, xylose, fucose, lactose, sucrose, sorbose, raffinose, cellulose, dulcitol, sorbitol, inositol, inulin or laminarin.

Metabolism of carbohydrates fermentative.

DNA base ratio 43 to 45 moles $\% \mathrm{G}+\mathrm{C}$.

Habitat: Sea water.

\section{Photobacterium Beijerinck, I 889}

Coccobacilli or occasional rods, pleomorphic forms frequently observed in adverse conditions of growth, motile by means of polar flagella or non-motile. Many strains appear to be non-motile as only a low proportion of the cells in a culture are seen to move actively and detection of flagella is difficult. Chemo-organotrophic, aerobic and facultatively anaerobic. Acid and gas or acid only produced from glucose and other carbohydrates but not lactose, do not attack complex carbohydrates or alcohols. Carbohydrate metabolism is fermentative. Nitrite produced from nitrate. Usually luminescent. Growth and luminescence occur on media containing 0.5 to $5 \% \mathrm{NaCl}$; optimum concentration $3 \% \mathrm{NaCl}$. Growth at $\mathrm{pH} 6$ to $\mathrm{pH}$ 9. Most strains grow at 5 but not at $37^{\circ}$. Usually sensitive to 2,4 -diamino-6,7-diisopropyl pteridine. DNA base ratio 39 to 42 moles $\% \mathrm{G}+\mathrm{C}$. Found living symbiotically in the tissues of luminous organs of cephalopods and deep-sea fishes and on the skin and in the intestine of some marine fish.

The type species is Photobacterium phosphoreum (Cohn) Ford.

Key to the species of the genus Photobacterium:

Coccobacilli which produce acid and usually gas from glucose.

A. Oxidase-negative, acid and usually gas from maltose, no growth at $37^{\circ}$. Photobacterium phosphoreum.

B. Oxidase-positive, no acid or gas from maltose, growth at $37^{\circ}$. Photobacterium mandapamensis.

Photobacterium phosphoreum (Cohn) Ford, 1927

(Synonyms: Micrococcus phosphoreus Cohn, 1878; Bacillusphosphorescens II Baumgarten, I888; Photobacterium phosphorescens Beijerinck, I889; Bacillus hermesi Trevisan, I889; Streptococcus phosphoreus (Cohn) Trevisan, I889; Bacillus phosphoreus (Cohn) Macé, I90I; Photobacter phosphorescens Beijerinck, I90I; Pseudomonas lucifera Molisch, 1904; Bacterium phosphoreum (Cohn) Molisch, I9I2; Photobacter phosphoreum (Cohn) Beijerinck, I9I6; Micrococcus physiculus Kishitani, I930; Coccobacillus acropoma Yasaki \& Haneda, I936; Coccobacillus macrouri; Acinetobacter phosphorescens Brisou, 1955; Photobacterium profundum Weisglass \& Gavrilovic, I963.)

Short rods or coccobacilli $\mathrm{I} \cdot 0$ to $2.5 \times 0.4$ to $\mathrm{I} \cdot 0 \mu \mathrm{m}$., occurring singly and occasionally in pairs, axis straight. Motile by a single polar flagellum, but only a small proportion of the cells in a culture are observed in motion. In stained specimens many pleomorphic cells are observed and polar staining frequently occurs. Gram-negative.

Sea-water agar colonies: Off-white, translucent, circular, convex, entire margin, smooth, shiny, I to $2 \mathrm{~mm}$. diameter. Luminous $\mathrm{I}$ to 3 days. Moderately good growth.

Sea-water broth: Moderately good growth, ring of dense growth at surface, slight uniform turbidity, granular deposit. 
No growth at $37^{\circ}$, most strains grow at $5^{\circ}$. Growth and visible light usually emitted in media containing 0.5 to $5 \% \mathrm{NaCl}$. No growth in $7.5 \% \mathrm{NaCl}$ or without $\mathrm{NaCl}$. Growth at $\mathrm{pH} 6$ to $\mathrm{pH} 9$.

Aerobic, facultatively anaerobic.

Sensitive to chloramphenicol, streptomycin, polymyxin B and 2,4-diamino-6,7diisopropyl pteridine; sensitivity to terramycin and aureomycin is variable. Insensitive to penicillin.

Nitrite produced from nitrate, acetylmethylcarbinol and 2,3-butanediol produced, ammonia produced from peptone, trimethylamine oxide reduced to trimethylamine. Indole not produced.

Methyl red test positive.

Oxidase-negative, catalase-positive.

Usually produces alkaline products from arginine and possesses a lysine decarboxylase but does not possess an ornithine decarboxylase.

Tweens 20 and 40 occasionally hydrolysed, Tweens 60 and 80 not hydrolysed.

No opalescence or free fatty acids produced on egg yolk agar.

Gelatin not usually liquefied.

Starch not hydrolysed.

Chitin usually digested.

Acid and usually gas formed in glucose, fructose, galactose, mannose and maltose and occasionally in ribose and fucose. No acid or gas formed in arabinose, rhamnose, xylose, lactose, sucrose, sorbose, cellobiose, trehalose, raffinose, cellulose, mannitol, dulcitol, glycerol, sorbitol, inositol, dextrin, salicin, inulin, laminarin, starch or glycogen.

Metabolism of carbohydrates fermentative.

DNA base ratio $39 \cdot 0$ to $42 \cdot 0$ moles $\% \mathrm{G}+\mathrm{C}$.

Habitat: Sea water.

\section{Photobacterium mandapamensis sp.nov.}

Short rods or coccobacilli $\mathrm{I} \cdot 0$ to $2 \cdot 5 \times 0 \cdot 4$ to $\mathrm{I} \cdot 0 \mu \mathrm{m}$., occurring singly and occasionally in pairs, axis straight. Motile by polar flagella. In stained specimens pleomorphic cells and polar staining may be observed. Gram-negative.

Sea-water agar colonies: Off-white, translucent, circular, convex, entire margin, smooth, shiny I to $2 \mathrm{~mm}$. diameter. Luminous I to 3 days. Moderately good growth.

Sea-water broth: Moderately good growth, thin pellicle, uniform turbidity, powdery deposit. Luminous 2 to 3 days.

Grows at $37^{\circ}$ but not at $5^{\circ}$. Growth and visible light usually emitted in media containing 0.5 to $5 \% \mathrm{NaCl}$. No growth without $\mathrm{NaCl}$ or in $7.5 \% \mathrm{NaCl}$. Growth at $\mathrm{pH} 6$ to $\mathrm{pH} 9$.

Aerobic, facultatively anaerobic.

Sensitive to chloramphenicol, streptomycin, polymyxin B and 2,4-diamino-6,7diisopropyl pteridine. Sensitivity to terramycin and aureomycin is variable. Insensitive to penicillin.

Nitrite produced from nitrate, trimethylamine oxide reduced to trimethylamine, ammonia produced from peptone, acetylmethylcarbinol produced but 2,3-butanediol not produced. Indole not produced.

Methyl red test positive. 
Oxidase- and catalase-positive.

Usually produces alkaline products from arginine and possesses a lysine decarboxylase, but not an ornithine decarboxylase.

Tweens 20 and 40 hydrolysed, Tweens 60 and 80 may be hydrolysed.

No opalescence or free fatty acid produced on egg yolk agar.

Gelatin may be slowly liquefied.

Starch not hydrolysed.

Chitin may be digested.

Acid and gas formed in glucose, fructose, galactose and mannose. No acid or gas formed in arabinose, rhamnose, ribose, xylose, fucose, lactose, sucrose, maltose, trehalose, sorbose, cellobiose, raffinose, cellulose, mannitol, dulcitol, sorbitol, glycerol, inositol, salicin, dextrin, inulin, laminarin, starch or glycogen.

Metabolism of carbohydrates fermentative.

DNA base ratio $42 \cdot 0$ moles $\% \mathrm{G}+\mathrm{C}$.

Habitat: Sea water.

\section{Lucibacterium gen.nov.}

Rods, motile by peritrichous flagella. In some strains the flagellation is of an unusual type with a thick polar flagellum in addition to the finer lateral flagella. Occasionally only the polar flagellum can be detected. Chemo-organotrophic. Aerobic, facultatively anaerobic. Carbohydrate metabolism is fermentative without the production of gas. Lactose not usually attacked. Gelatin liquefied. Nitrite produced from nitrate. Oxidase-positive. Insensitive to 2,4-diamino-6,7-diisopropyl pteridine. Usually luminescent. Growth and luminescence occurs on media containing 0.5 to $5 \% \mathrm{NaCl}$, optimum concentration $3 \% \mathrm{NaCl}$. Growth at $\mathrm{pH} 6$ to $\mathrm{pH} 9$. Usually grows at $37^{\circ}$ but not at $5^{\circ}$. DNA base ratio 45 to 46 moles $\% \mathrm{G}+\mathrm{C}$. Found on the surface of dead fish and in sea water.

The type species is Lucibacterium harveyi (Johnson \& Shunk) comb.nov.

\section{Lucibacterium harveyi (Johnson \& Shunk)}

(Synonyms: Achromobacter harveyi Johnson \& Shunk, 1936; Photobacterium splendidum (Beijerinck) Eymers \& van Schouwenburg, 1937; Photobacterium sepiae Kluyver, 1938; Photobacterium harveyi (Johnson \& Shunk) Breed \& Lessel, I954; Pseudomonas harveyi (Johnson \& Shunk) Krassil'nikov, 1959.)

Rods, I. 2 to $4 \cdot 0 \times 0.3$ to $\mathrm{I} \cdot 0 \mu \mathrm{m}$., straight or slightly curved, sides parallel, ends rounded, occurring singly and in pairs. Pleomorphic form may be present. Motile by means of peritrichous flagella. Flagellation may be of an unusual type showing a thick polar flagellum in addition to many fine lateral flagella. In some strains only the polar flagellum can be detected. Gram-negative.

Sea-water agar colonies: Off-white, translucent, circular, convex, entire margin, smooth, shiny, I to $3 \mathrm{~mm}$. diameter. Colonies frequently mucoid and tend to spread. Abundant growth. Luminous after I, 2 or 3 days.

Sea-water broth: Good growth, thin pellicle, uniform turbidity, flocculent deposit. Luminous.

Usually grows at $37^{\circ}$ but not at $5^{\circ}$. Grows in media containing 0.5 to $7.5 \% \mathrm{NaCl}$, 
but not in media without $\mathrm{NaCl}$. Visible light emitted in media containing 0.5 to $5 \%$ $\mathrm{NaCl}$. Growth at $\mathrm{pH} 6$ to $\mathrm{pH} 9$.

Aerobic, facultative anaerobic.

Sensitive to chloramphenicol, streptomycin, aureomycin, may be sensitive to terramycin. Insensitive to penicillin and 2,4-diamino-6,7-diisopropyl pteridine.

Indole produced, nitrite produced from nitrate, ammonia produced from peptone, trimethylamine oxide reduced to trimethylamine.

Acetylmethylcarbinol and 2,3-butanediol not produced.

Methyl red test positive.

Oxidase- and catalase-positive.

Usually possesses decarboxylases for lysine and ornithine, but does not usually produce alkaline products from arginine.

Tweens 20, 40,60 and 80 hydrolysed.

Opalescence and free fatty acids produced in egg yolk agar.

Gelatin liquefied.

Starch hydrolysed.

Chitin digested.

Acid but no gas produced from glucose, fructose, galactose, mannose, maltose, cellobiose, trehalose, mannitol, sorbitol, dextrin, laminarin, starch and glycogen. Acid may be produced from ribose, sucrose, glycerol, salicin and occasionally from lactose (weak). No acid or gas from arabinose, rhamnose, xylose, fucose, sorbose, raffinose, cellulose, dulcitol, inositol or inulin.

Metabolism of carbohydrates fermentative.

DNA base ratio 45 to 46 moles $\% \mathrm{G}+\mathrm{C}$.

Habitat: Sea water.

\section{REFERENCES}

BAIN, N. \& Shewan, J. M. (1968). Identification of Aeromonas, Vibrio and related organisms. In Identification Methods for Microbiologists, part B, pp. 79-84. Edited by B. M. Gibbs \& D. A. Shapton. London and New York: Academic Press.

BeIJerINCK, M. W. (I889). Le Photobacterium luminosum, bactérie lumineuse de la Mer du Nord. Archives néerlandaises des sciences exactes et naturelles 23, 40I-415.

BeIJERINCK, M. W. (1916). Die Leuchtbakterien der Nordsee im August und September. Folia Microbiologica, Delft 4, I5-40.

Bergey's MANual of Determinative Bacteriology (1957), 7 th edn. Edited by R. S. Breed, E. G. D. Murray \& N. R. Smith. London: Baillière Tindall and Cox.

BReEd, R. S. \& LeSSEL, E. F. (1954). The classification of luminescent bacteria. Antonie van Leeuwenhoek 20, 58-64.

BRENNER, S. \& HoRNE, R. W. (1959). A negative staining method for high resolution electron microscopy of viruses. Biochimica et biophysica acta 37, 103-110.

BuLloCK, G. L. (196I). A schematic outline for the presumptive identification of bacterial diseases of fish. Progressive Fish Culturist 23, 147-I5I.

CanN, D. C. \& Willox, M. E. (1965). Analysis of multimolecular enzymes as an aid to the identification of certain rapidly growing mycobacteria using starch gel electrophoresis. Journal of Applied Bacteriology 28, 165-173.

Carpenter, K. P., Hart, J. M., Hatpield, J. \& Wicks, G. (1968). Identification of human vibrios and allied organisms. In Identification Methods for Microbiologists, part B, pp.9-18. Edited by B. M. Gibbs \& D. A. Shapton. London and New York: Academic Press.

Colwell, R. R. \& MANDEL, M. (1964). Base composition of deoxyribonucleic acid from marine and non-marine vibrios deduced from buoyant-density measurements in cesium chloride. Journal of Bacteriology 88, 1816-1817. 
Colwell, R. R. \& MoRITA, R. Y. (1964). Reisolation and emendation of description of Vibrio marinus (Russell) Ford. Journal of Bacteriology 88, 83I-837.

CraWford, I. P. (1954). A new fermentative pseudomonad, Pseudomonas formicans n.sp. Journal of Bacteriology 68, 734-738.

Ferguson, W. W. \& Henderson, N. D. (1947). Description of strain C 27: a motile organism with the major antigen of Shigella sonnei phase I. Journal of Bacteriology 54, 179-181.

Follett, E. A. C. \& Gordon, J. (1963). An electron microscope study of Vibrio flagella. Journal of General Microbiology 32, 235-239.

Hill, L. R. (I966). An index to deoxyribonucleic acid base compositions of bacterial species. Journal of General Microbiology 44, 419-437.

Hodgkiss, W. \& Shewan, J. M. (I950). Pseudomonas infection in plaice. Journal of Pathology and Bacteriology 62, 655-657.

Hugh, R. \& LeIfSON, E. (1953). The taxonomic significance of fermentative versus oxidative metabolism of carbohydrates by various Gram-negative bacteria. Journal of Bacteriology 66, 24-26.

Index Bergeyana. (1966). Edited by R. E. Buchanan, J. G. Holt \& E. F. Lessel. Edinburgh: E. and S. Livingstone.

Johnson, F. H. \& Shunk, I. V. (1936). An interesting new species of luminous bacteria. Journal of Bacteriology 3r, 585-592.

JOHNSON, F. H., ZWORYKIN, N. \& WARREN, G. (I943). A study of luminous bacterial cells and cytolysates with the electron microscope. Journal of Bacteriology 46, 167-185.

Kovacs, N. (1956). Identification of Pseudomonas pyocyanea by the oxidase reaction. Nature, London 178,703 .

KrassiL'nIKov, N. A. (I959). Diagnostik der Bakterien und Actinomyceten. Jena: Gustav Fischer Verlag.

LEIFSON, E. (1963). Determination of carbohydrate metabolism of marine bacteria. Journal of Bacterio$\log y 85$, I I 83-I I 84 .

Liston, J. (1955). A group of luminous and non-luminous bacteria from the intestine of flatfish. Journal of General Microbiology 12, i.

McElroy, W. D. (196I). Bacterial luminescence. In The Bacteria, vol. 2. Metabolism, pp. 479-508. Edited by I. C. Gunsalus \& R. Y. Stanier. New York and London: Academic Press.

MACKIE AND MCCARTNEY's HANDBOOK OF BACTERIOLOGY (1960). Ioth edn, pp. I12-I13. Edited by R. Cruickshank. Edinburgh: E. and S. Livingstone.

MANDEL, M. (1966). Deoxyribonucleic acid base composition in the genus Pseudomonas. Journal of General Microbiology 43, 273-292.

Manual of Microbiological Methods (1957). Society of American Bacteriologists Committee on Bacteriological Technic. New York: McGraw-Hill.

MARMUR, J. (196I). A procedure for the isolation of DNA from micro-organisms. Journal of Molecular Biology 3, 208-218.

Marmur, J. \& Doty, P. (I962). Determination of the base composition of DNA from its thermal denaturation temperature. Journal of Molecular Biology 5, 109-1 I 8.

Miles, E. M. \& Miles, A. A. (I95I). The identity of Proteus hydrophilus Bergey et al. and Proteus melanovogenes Miles \& Halnan, and their relation to the genus Aeromonas Kluyver \& van Niel. Journal of General Microbiology 5, 298-306.

Møller, V. (1955). Simplified tests for some amino acid decarboxylases and for the arginine dihydrolase system. Acta pathologica et microbiologica scandinavia 36, I 58-172.

OgaSAWARA, K. \& Kuno, T. (1964a). Electron microscopy of structure of flagellum of Vibrio comma. Nagoya Journal of Medical Science 26, 99-108.

OGASAWARA, K. \& KUNO, T. (1964b). Electron microscopy of flagellation of Vibrio parahaemolyticus. Nagoya Journal of Medical Science 26, 109-I 18.

Prvnick, H. \& Sabina, L. R. (1957). Studies of Aeromonas formicans Crawford comb.nov. from soluble oil emulsions. Journal of Bacteriology 73, 247-252.

Prévot, A. R. (196I). Traité de Systématique Bactérienne. Paris: Dunod.

Rosypal, S. \& Rosypalova, A. (I966). Genetic, phylogenetic and taxonomic relationships among bacteria as determined by their deoxyribonucleic acid base composition. Folia, Faculty of Natural Sciences, J. E. Purkyne University, Brno 7, 1-91. 
Journal of General Microbiology, Vol. 64, No. 2

Plate I
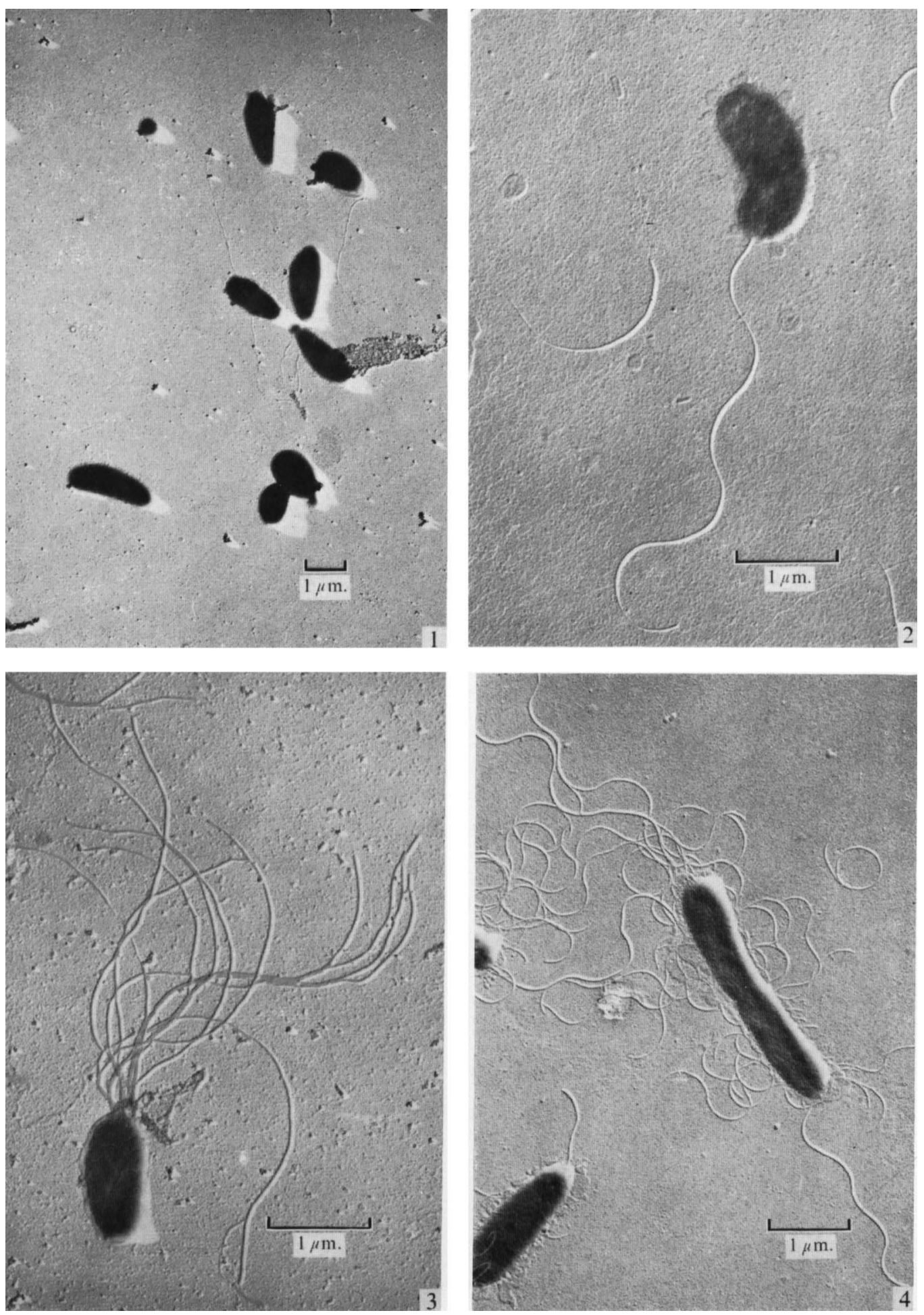

M. S. HENDRIE, W. HODGKISS AND J. M. SHEWAN

(Facing p. I68) 
Journal of General Microbiology, Vol. 64, No. 2

Plate 2
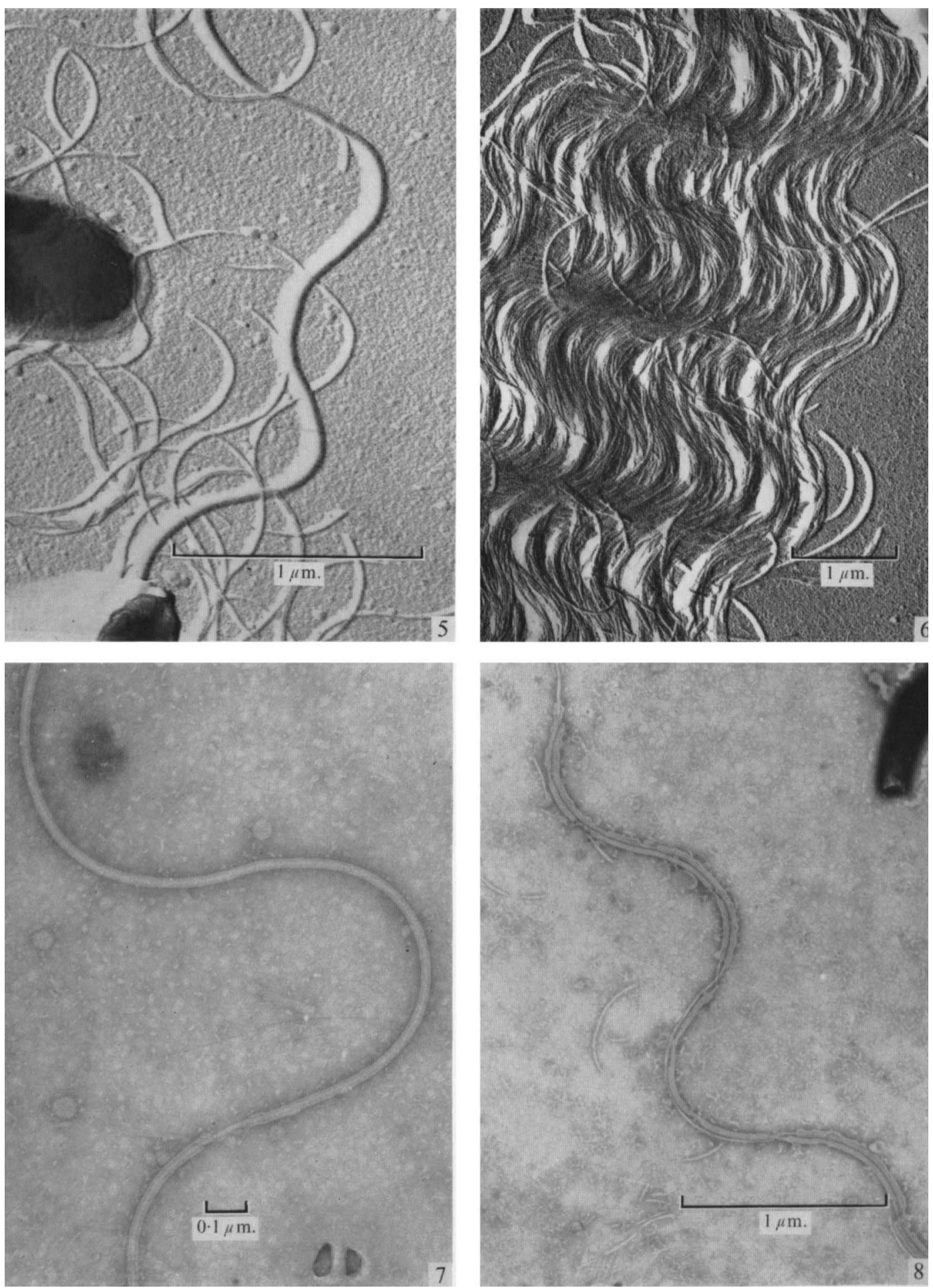

M. S. HENDRIE, W. HODGKISS AND J. M. SHEWAN 
SChubert, R. H. W. (1962). Zur Technik der Differenzierung von Vibrionen und Pseudomonaden mit dem Vibriostaticum o/129. Zentralblatt für Bakteriologie, Parasitenkunde, Infektionskrankheiten und Hygiene (Abteilung I Originale) 184, 560-561.

ShEWAN, J. M., HobBs, G. \& HodGKISs, W. (I960). A determinative scheme for the identification of certain genera of Gram-negative bacteria, with special reference to the Pseudomonadaceae. Journal of Applied Bacteriology 23, 379-390.

Shewan, J. M., Hodgkiss, W. \& Liston, J. (1954). A method for the rapid differentiation of certain non-pathogenic asporogenous bacilli. Nature, London 173, 208-209.

SierRA, G. (1957). A simple method for the detection of lipolytic activity of micro-organisms and some observations on the influence of the contact between cells and fatty substrates. Antonie van Leeuwenhoek 23, 15-22.

SPENCER, R. (1955). The taxonomy of certain luminous bacteria. Journal of General Microbiology r3, II I-II 8.

SPENCER, R. (196I). Chitinoclastic activity in the luminous bacteria. Nature, London 190, 938.

VÉron, M. \& Sebald, M. (1964). Sur la teneur en bases de l'ADN et al position taxonomique de Vibrio ichthyodermis Shewan, Hobbs et Hodgkiss, 1960. Annales de l'Institut Pasteur, Paris 107, 422-423.

Weisglass, H. \& Gavrilovic, B. (1963). Photobacterium profundum sp.n. Bulletin scientifique. Conseil des academies de la RPF Yougoslavie 8, 69-70.

WeISGLASS, H. \& SKreb, Y. (1963). Vibrio noctiluca sp.n. Bulletin scientifique. Conseil des academies de la RPF Yougoslavie 8, 9.

WILLIS, A. T. \& HoBBs, G. (I958). A medium for the identification of clostridia producing opalescence in egg-yolk emulsions. Journal of Pathology and Bacteriology 75, 299-305.

WooD, A. J. \& BAIRD, E. A. (I943). Reduction of trimethylamine oxide by bacteria. I. The Enterobacteriaceae. Journal of the Fisheries Research Board of Canada 6, 194-20r.

ZoBell, C. E. (1946). Marine Microbiology, p. 58. Waltham, Mass.: Chronica Botanica Co.

\section{EXPLANATION OF PLATES}

All the photographs are electron micrographs of preparations from cultures incubated at $20^{\circ}$ on SWYP agar for $24 \mathrm{~h}$. and fixed in $5 \%(\mathrm{v} / \mathrm{v})$ formalin in $2.5 \% \mathrm{NaCl}$. Fig. I to 6 inclusive are of gold + palladium shadowed preparations. Fig. 7 and 8 are of specimens negatively stained with phosphotungstic acid.

\section{Plate I}

Fig. I. Photobacterium phosphoreum NCMB 7.

Fig. 2. Lucibacterium harveyi NCMB I (Photobacterium splendidum).

Fig. 3. Vibrio fischeri NCMB 1281 (Photobacterium fischeri).

Fig. 4. Lucibacterium harveyi NCMB I 280 (Photobacterium harveyi).

Plate 2

Fig. 5. Lucibacterium harveyi NCMB I280 (Photobacterium harveyi). Thick and thin flagella.

Fig. 6. Lucibacterium harveyi NCMB 1280 (Photobacterium harveyi). Fascicles of thin flagella.

Fig. 7. Lucibacterium harveyi NCMB 1280 (Photobacterium harveyi). Thick (polar) flagellum showing core and sheath.

Fig. 8. Lucibacterium harveyi NCMB I 280 (Photobacterium harveyi). Two thick (polar) flagella showing disintegration of the sheath. 